\section{Diagnostic path of a genetic disease: a case of Williams- Beuren syndrome in Burkina Faso}

\author{
Makoura Barro, Bintou Sanogo, \\ Aimée S. Kissou, Ad Bafa Ibrahim \\ Ouattara, Boubacar Nacro \\ Department of Pediatrics, Souro Sanou \\ Teaching Hospital, Bobo-Dioulasso, \\ Burkina Faso
}

\section{Abstract}

Williams-Beuren syndrome (WBS) is a rare neurodevelopmental disorder characterized by a set of somatic, psychological, and behavioral abnormalities, which is caused by a deletion of several genes. Herein we report a 6 year-old boy, who presented with mental retardation and psychological disorders. The result of the first clinical examination was poor, since it didn't detect any dysmorphic feature which is a major component for the clinical diagnosis of WBS. Despite the multidisciplinary and the multicenter approaches used, the diagnosis of WBS (deletion of chromosome band 7q11.23) was established more than 3 years after the first medical consultation. Rare partial forms of WBS have been recently described and they are both clinically and genetically difficult to diagnose. Unfortunately, this disorder is still little known by health professionals.

\section{Introduction}

Williams-Beuren syndrome (WBS), is a rare genetic neurodevelopmental disorder characterized by a set of somatic, psychological, and behavioral disorders.1,2 Little is known about WBS in last developed and developing countries; this disease is under-diagnosed or diagnosed late, which causes several consequences on both somatic and psychological aspects. $^{2}$

In Africa, a genetic disease such as Williams's syndrome is often discovered incidentally. In fact, molecular biology, which is essential for a qualitative diagnosis, is expensive and a proper examination can be achieved only in specialized laboratories which are absent in Burkina Faso. Once diagnosed, it should be treated with a multidisciplinary approach, by involving pediatrician, pediatric cardiologist, orthodontist, psychomotor, psychologist, etc., which also is a problem. ${ }^{2,3}$

The aim of our study is to examine the diag- nosis of a case of WBS received at Pediatric Department, Bobo Dioulasso Teaching Hospital (CHUSS).

\section{Case Report}

\section{History of the disease}

A.T., a 6-year-old male, was admitted at Bobo-Dioulasso Teaching Hospital (Burkina Faso) in 2007 as per his parents' request. Since he was 1-year-old, A.T. had significant psychomotor disturbance, a delay in sitting, walking and language. Until his 6 years old, A.T. was always stage words difficult to schooling. He also showed some psychomotor agitation, passing spontaneously from one activity to another without attention. Following this consultation, diagnostic hypothesis of brain damage of scalable etiology, unnoticed at birth, was mentioned. To further investigate, a brain scan was done in Burkina Faso and a standard karyotype was performed in a laboratory in France, but the results were normal. A.T. subsequently received EEG in Senegal which was also normal; therefore no explanation was found regarding his psychomotor disability.

However, he received a psychiatric institutional care and education in Burkina Faso, which have slightly improved AT language in structuring process, according to his parents.

In June 2007, A.T. had a psychiatric and pediatric consultation in France. Following these consultations, further chromosome study and a metabolic check were performed.

\section{Antecedents}

A.T. was born after a full-term pregnancy, with no neonatal complications. His birth weight was $2500 \mathrm{~g}$, length was $48.5 \mathrm{~cm}$ and head circumference was $33 \mathrm{~cm}$. No sleep or feeding disorder has been reported. A.T. learned to sit at 10 months and walked at 26 months.

He has always been hyperactive, making it difficult to capture his attention. At kindergarten he was described as an aggressive child towards his classmates, especially during the first months. He likes music and is sociable with adults. A.T. has received surgery for bilateral cryptorchidism and umbilical hernia.

\section{Clinical diagnosis}

A.T. presented for admission in a psychiatric unit in France. Psychotic disorders with a significant delay in the awakening including language delay were reported. He seemed to understand simple orders, but he obviously had trouble in understanding for more complex instructions. He couldn't make a sentence, but had very few words he used wisely. An important restlessness was reported due to
Correspondence: Makoura Barro, Department of Pediatrics, Souro Sanou Teaching Hospital, 01 BP 676, Bobo-Dioulasso 01, Burkina Faso.

E-mail: barro.mak@fasonet.bf

Key words: Williams-Beuren; neurodevelopmental disorder; deletion 7q11.23.

Acknowledgements: this study hasn't received funding from any sources, but technical support was generously provided by Pediatric Department at Bobo Dioulasso Teaching Hospital in Burkina Faso.

Contributions: the authors contributed equally.

Conflict of interest: the authors declare no poten tial conflict of interest.

Received for publication: 17 January 2015. Accepted for publication: 6 October 2015.

This work is licensed under a Creative Commons Attribution NonCommercial 3.0 License (CC BYNC 3.0).

(C) Copyright M Barro et al., 2015

Licensee PAGEPress, Italy

Pediatric Reports 2015; 7:5817

doi:10.4081/pr.2015.5817

his impossibility to focus on one activity and instability; which gave the impression of a very high dispersion. He had a cognitive level of about 24-30 months according to the revised Brunet-Lezine. He was also admitted at the center of Medico-Social Action Early. Physical examination gave the following results: lack of facial dysmorphic craniofacial, presence of a small penis, weight $19 \mathrm{~kg}$, height $108 \mathrm{~cm}$, head circumference $47.5 \mathrm{~cm}$, no physical abnormalities.

\section{Paraclinical diagnosis}

In June 2007, a detailed chromosomal investigation better than karyotype was requested by the pediatrician; the Center gave the following results: normal 46XY karyotype (500 bands); no micro deletion 15q11, 15q22, 22q11, 22qter; negative X-fragile checkup; normal metabolic checkup.

Further genetic investigations were required by using different genetics techniques at the same center in France. So, in February 2010, a deletion of chromosome 7 (7q11. 23) was identified through array comparative genomic hybridization (CGH-array)

\section{Evolution-prognosis}

The patient, after staying in France for a month, returned back in Burkina Faso in late July 2007. Currently, he's 12-years-old and attends elementary school (second year). His 
neuropsychological disturbances persist. All evolutionary signs could not be assessed because the child does not receive any followup.

\section{Discussion}

The incidence of typical forms of WBS is 1:7500 live births, but the partial form is still poorly understood in developing countries.1,2 To our knowledge, this is the first case reported in Burkina Faso.

A clinical diagnosis can be easily established in individuals with classic features of WBS (e.g., supravalvular aortic stenosis, characteristic facial features/neurocognitive profile, hypercalcemia, etc); in individuals with a less classic presentation, the paucity of clinical features may not support clinical suspicion. 4 Our patient had only a cognitive and language delay with a very specific behavior. Indeed, although a very evocative facial dysmorphia, a discerning eye is required. ${ }^{5}$ Rösch in his comments confess that I have bonded this phenotype to hospitalized children only after its release retrospectively, three years later. ${ }^{5}$

Rare forms of partial WBS have been reported with attenuated symptoms, including dysmorphic ones, that must be taken into consideration together with a specific behavioral phenotype, as in our case. 6,7

The partial forms seem correlated to smaller deletions and to the nature of genes. The clinical features of our patient and the use of standard methods did not allow practitioners from Burkina Faso, or those from France or Senegal, to suspect this disease. The mental retardation and the child behavior remained unexplained for 3 years. This was essentially due to the following reasons: i) WBS is a little-known pathology among health professionals; ii) our patient probably had the partial form, which is more complicated to recognize; iii) practitioners have faced extensive diagnostic category of mental retardation; in this case we needed to use CGH-array to detect WBS. 3,8

\section{Conclusions}

Williams-Beuren syndrome is a rare clinical entity with homogeneous genetic characteristics. The diagnosis could be easily reached when the clinical picture is complete and the patients present with the classic WBS features. Rare partial forms of WBS have been recently described, but they are still difficult to diagnose both clinically and genetically. Unfortunately, this disorder is still little known among health professionals, especially in developing countries such as Burkina Faso. Therefore, it is still necessary to continue investigations.

\section{References}

1. Leme DE, Souza DH, Mercado G. et al. Assessment of clinical scoring systems for the diagnosis of Williams-Beuren syn- drome. Genet Mol Res 2013;12:3407-11.

2. Baubet T. Le syndrome de Williams importance d'une prise en charge pluridisciplinaire précoce. J Pédiatrie Puériculture 1999;12:225-30.

3. Lacroix A, Pezet M, Capel A, et al. Le syndrome de Williams-Beuren: une approche pluridisciplinaire. Arch Pédiatr 2009;16 :273-82.

4. Koehler U, Pabst B, Pober B, Kozel B. Clinical utility gene card for: WilliamsBeuren Syndrome [7q11.23]. Eur J Hum Genet 2014;22.

5. Rösch D. Ré-éducation et pédagogie dans le syndrome de Williams-Beuren. La place de la clinique dans l'accompagnement au long cours d'enfants porteurs du syndrome. Neuropsychiatr Enfance Adolesc 2004;52:430-7.

6. Tekendo-Ngongang C, Dahoun S, Nguefack S, et al. Challenges in clinical diagnosis of Williams-Beuren syndrome in Sub-Saharan Africans: case reports from Cameroon. Mol Syndromol 2014;5:287-92.

7. Karmiloff-Smith A, Grant J, Ewing S, et al. Using case study comparisons to explore genotype-phenotype correlations in Williams-Beuren syndrome. J Med Genet 2003;40:136-40.

8. Béri-Dexheimer M, Bonnet C, Chambon $\mathrm{P}$, et al. L'hybridation génomique comparative sur micro-réseau d'ADN (puces à ADN) en pathologie chromosomique constitutionnelle. Pathol Biol 2007;55:13-8. 